\section{Pediatric pyogenic sacroiliitis and osteomyelitis}

\author{
Sushant Srinivasan, Carl Miller, \\ Nour Akhras, Alexander R. Blackwood \\ Department of Pediatrics and Communi- \\ cable Diseases, University of Michigan \\ Medical School, Ann Arbor, MI, USA
}

\begin{abstract}
Pyogenic sacroiliitis accounts for $1-2 \%$ of all cases of septic arthritis with less than 200 cases reported in the English literature since the beginning of the twentieth century. Cultures of joint fluid usually grow Staphylococcus aureus. Prognosis is excellent; however, diagnosis may be difficult due to rarity of disease and non-specific signs, symptoms, and physical findings. Magnetic resonance imaging has been found to be the most useful imaging modality in diagnosis. Most reported cases required prolonged antimicrobial therapy of six to nine weeks. Presented here are two children with pyogenic sacroiliitis managed at a tertiary-care, university hospital and review of the literature on this relatively rare diagnosis.
\end{abstract}

\section{Case Report \#1}

A 12-year-old girl presented with a 5-day history of acute onset, non-radiating, right posterolateral hip pain. The pain was initially accompanied by local swelling without erythema and progressively worsened limiting ambulation. There was no history of nausea, vomiting, diarrhea, fever, or rash; however, there was a one-day history of sore throat one week prior to presentation. Past medical, surgical, social, and familial history was non-contributory. Vital signs were notable for a temperature of 38.6 degrees Celsius and heart rate of 123 beats per minute. Physical examination was notable for severe pain at the right hip joint with passive and active flexion, extension, and internal and external rotation. Neuromuscular function was intact and the remainder of the physical exam was unremarkable. Laboratory studies demonstrated a white blood cell count of 12,200 cells per cubic millimeter with $77.7 \%$ neutrophils, anti-streptolysin 0 antibody of 657 international units per milliliter, erythrocyte sedimentation rate of 84 millimeters per hour, C-reactive protein of 15.1 milligrams per deciliter and a creatinine phosphokinase of 113 international units per liter. Roentogram and ultrasonogram of the right hip were negative. Computed tomography with oral and intravenous contrast of the abdomen, pelvis, and hips was negative. The patient was admitted for further evaluation and begun on intravenous Ceftriaxone, high dose aspirin alone, and morphine. Vancomycin was added when blood cultures became positive for gram positive cocci in clusters (later identified as methicillin-sensitive Staphylococcus aureus) within twenty-four hours. Magnetic resonance imaging of the lumbar spine demonstrated increased joint fluid in the right sacroiliac joint with bone marrow edema in the adjacent right sacrum and increased signal and enhancement of the superior aspect of the right piriformis adjacent to the sacroiliac joint, confirming a diagnosis of septic sacroiliitis with associated piriformis pyomyositis. The patient was evaluated by Pediatric Orthopedic Surgery who determined that surgical debridement was not necessary. The patient was discharged on oral Trimethoprim-Sulfamethoxazole, ambulating with only a slight limp.

The patient was seen in follow-up, approximately one month after discharge and was noted to have persistent right hip pain requiring a walker for ambulation. The erythrocyte sedimentation rate had increased to 70 millimeters per hour from 44 at discharge. A repeat magnetic resonance imaging (MRI) and computed tomography (CT) showed no evidence of a sequestrum. Poor patient compliance was noted due to nausea; antibiotics were changed to Cephalexin and Rifampin. One month later the patient experienced a significant decrease in pain and was ambulating without an aid. Erythrocyte sedimentation rate (ESR) was 17 and antibiotics were continued for a total course of three months with full recovery.

\section{Case Report \#2}

A previously healthy 23-month-old male presented with four separate episodes, over a 2 month period, of refusing to bear weight on his right lower extremity. The first episode lasted for eight hours, self-resolved, but recurred a couple of weeks later. Each episode had a sudden onset, lasted a few hours longer than the previous episode, and then resolved. There was no fever or other associated symptoms or physical finding. There was no history of trauma or concurrent recent illnesses.

Bilateral roentograms of lower extremities during the second episode were normal. An MRI of his right lower extremity obtained during the third episode was normal. However, a CT of the right sacrum demonstrated sclerosis and periosteal irregularity of the right superior sacroiliac joint. An MRI of the right sacrum revealed a focus of low $\mathrm{T} 1$ and high T2 signal in the upper aspect of the right sacrum, and the patient was referred to pediatric orthopedic surgery and infectious diseases.
Correspondence: Alexander Blackwood, Pediatrics Department of Pediatrics and Communicable Diseases, University of Michigan Medical School, D5101 Medical Professional Building/SPC 5718

1500 East Medical Center Drive, Ann Arbor, MI 48109-5718, USA.

Tel. +1.734.763.2440 - Fax: +1.734.232.3859.

E-mail: rab@umich.edu

Key words: septic arthritis, Staphylococcus, rare disease, antimicrobial therapy.

Conflict of interest: the authors report no conflicts of interest.

Received for publication: 25 March 2011.

Revision received: 15 November 2011.

Accepted for publication: 30 January 2011.

This work is licensed under a Creative Commons Attribution NonCommercial 3.0 License (CC BYNC 3.0).

@C Copyright S. Srinivasan et al., 2012

Licensee PAGEPress srl, Italy

Infectious Disease Reports 2012; 4:e18

doi:10.4081/idr.2012.e18

In clinic the patient ambulated with a heelto-toe progression, was able to go up on his toes without any problems, had full range of motion about the hips and knees, had full flexion and extension of bilateral lower extremities, and had symmetric range of motion with internal rotation approximately 30 degrees and external rotation approximately 80 degrees. There was no notable swelling of the joints and the spine was straight. No sacral dimple or hair tuft noted. No abdominal masses palpable. His thigh-foot angle was 0 . Laboratory evaluation revealed a white blood cell count of 10,400 cells per cubic millimeter with $50 \%$ neutrophils and $40 \%$ lymphocytes. His C-reactive protein was 0.1 milligrams per deciliter and his erythrocyte sedimentation rate was 16 millimeters per hour. Bone scan revealed a small focus of mildly increased tracer uptake in the right sacrum and a biopsy culture grew out coagulase-negative Staphylococcus that was methicillin susceptible. The patient received intravenous Cefazolin for eight weeks followed by four months of an oral first generation cephalosporin without any recurrences of pain or refusal to bear weight on his right lower extremity.

\section{Discussion}

The evaluation of a child with a limp involves consideration of several potential etiologies including infection, fracture, and rheumatic arthritis. ${ }^{1}$ Septic sacroiliitis, also known 
as pyogenic sacroiliitis (PS), is an uncommon diagnosis in the pediatric patient, accounting for one to two \% of all cases of septic arthritis, ${ }^{2}$ with fewer than 200 cases of PS having been reported in the English literature ${ }^{3}$ since the beginning of the twentieth century.

Schaad et al. ${ }^{4}$ reported 77 patients with sacroiliitis between 1961 and 1980 noting that infection was more common in boys during late childhood and in boys often presenting sub-acutely. Bone scans were generally helpful in making the diagnosis, and aspiration of the joints frequently revealed Staphylococcus aureus as the infecting agent. Management frequently required antibiotic targeted towards Staphylococcus aureus and surgical debridement or drainage and the prognosis was excellent.

Since 1980, there have been six case series which included five or more children $(<18$ years old) that include outcomes. Staphylococcus aureus was the most frequently recovered pathogen (12 of 16; 75\% including our cases); however, case reports have also identified Salmonella ${ }^{5}$ and Brucella ${ }^{6,7}$ as less frequent organisms. Previously there were a total number of 39 patients in the six case series

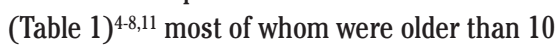
years, although the youngest reported child was 20 months old. Preceding trauma (9 of 25)

Table 1. Patient data.

\begin{tabular}{|c|c|c|c|c|c|c|c|c|c|}
\hline Article & $\begin{array}{l}\text { Schaad et al. } \\
\text { (1980) }\end{array}$ & $\begin{array}{r}\text { Ncube }^{8} \\
(1988)\end{array}$ & $\begin{array}{c}\text { Moyer et al. }{ }^{9} \\
(1990)\end{array}$ & $\begin{array}{l}\text { Abbott \& } \\
\text { Carty10 }^{10} \\
(1993)\end{array}$ & $\begin{array}{l}\text { Aprin \& } \\
\text { Turen }^{11} \\
\text { (1993) }\end{array}$ & $\begin{array}{c}\text { Doita et al. } \\
\text { (2003) }\end{array}$ & Subtotals & 2 cases & Total \\
\hline Number of children & ren & 6 & 6 & 9 & 7 & 5 & 39 & 2 & 41 \\
\hline Age range (years) & $2-12$ & $6-14$ & $1.5-15$ & $20 \mathrm{mo}-14$ & $2-16$ & $12-15$ & $20 \mathrm{mo}-16$ & $23 \mathrm{mo}$ & \\
\hline 12 & $20 \mathrm{mo}-16$ & & & & & & & & \\
\hline Male:Female & $4: 2$ & $1: 5$ & $5: 1$ & $5: 4$ & $2: 5$ & $2: 3$ & 19:20 & $1: 1$ & $20: 21$ \\
\hline Side R:L & $1: 5$ & $2: 4$ & $2: 4$ & $5: 4$ & NR & $\begin{array}{c}2: 2 \text { (one low } \\
\text { back pain) }\end{array}$ & $12: 19$ & $2: 0$ & 14:19 \\
\hline Preceding trauma & $1 / 6$ & $3 / 6$ & $3 / 6$ & NR & $2 / 7$ & NR & $9 / 25$ & $0 / 2$ & $9 / 27$ \\
\hline Preceding infection & NR & $\begin{array}{c}3 / 6(2 \\
\text { pharyngitis, } \\
1 \text { purulent } \\
\text { paronychia })\end{array}$ & $\begin{array}{c}1 / 6 \\
\text { (pharyngitis) }\end{array}$ & $\begin{array}{l}\text { 4/9 (cough, } \\
\text { tonsillitis } \times 3 \text { ) }\end{array}$ & $1 / 7$ & None & $9 / 28$ & $0 / 2$ & $9 / 30$ \\
\hline Duration of Sx & 1.5wks-6wks & 2d-7d & $9 \mathrm{~d}-28 \mathrm{~d}$ & NR & $4 d-28 d$ & $2 d-8 d$ & $2 \mathrm{~d}-6 \mathrm{wk}$ & $5 \mathrm{~d}, 2 \mathrm{mo}$ & $2 \mathrm{~d}-2 \mathrm{mo}$ \\
\hline WBC range & $6.1-14$ & $9.0-17.0$ & $6.6-18.6$ & $6.0-22.1$ & $8.9-16.7$ & $5.2-14.1$ & $5.2-22.1$ & $12.2,10.4$ & $5.2-22.1$ \\
\hline ESR range & $50-127$ & $31-98$ & $55-106$ & $10-110$ & $39-84$ & $49-88$ & $10-127$ & 84,16 & $10-127$ \\
\hline Blood culture & NR & $\begin{array}{l}3 / 6 \text { positive for } \\
\text { Staphylococcus } \\
\text { aureus; One ASO } \\
\text { positive with } \\
\text { negative } \\
\text { blood culture }\end{array}$ & $\begin{array}{c}3 / 6 \text { for } \\
\text { Staphylococcus } \\
\text { aureus }\end{array}$ & $\begin{array}{c}\text { 3/9 positive, } \\
\text { 2 Staphylococcus } \\
\text { aureus, } \\
1 \text { E. coli }\end{array}$ & $\begin{array}{l}\text { 4/7 positive, } \\
\text { (1 Streptococcus } \\
\text { pneumonia, } \\
1 \text { Escherichia coli, } \\
2 \text { Staphylococcus } \\
\text { aureus) }\end{array}$ & $\begin{array}{c}2 / 2 \\
\text { Staphylococcus } \\
\text { aureus }\end{array}$ & $15 / 30$ & $\begin{array}{c}\text { 1/2 positive } \\
\text { Staphylococcus } \\
\text { aureus }\end{array}$ & $16 / 32$ \\
\hline Aspirate culture & $\begin{array}{c}\text { Pos 4/4, } \\
\text { not specified }\end{array}$ & ND & $\begin{array}{c}\text { 2/3 (1 } \\
\text { Staphylococcus } \\
\text { aureus, } \\
\text { 1 Haemophilus } \\
\text { influenzae) }\end{array}$ & $\begin{array}{c}\text { 2/2 (both } \\
\text { Staphylococcus } \\
\text { aureus) }\end{array}$ & $2 / 2$ & $0 / 2$ & $10 / 13$ & $\begin{array}{c}1 \\
\text { coag positive/ } \\
1 \text { coag } \\
\text { negative } \\
\text { Staph }\end{array}$ & $12 / 15$ \\
\hline Initial X-ray & $2 / 6$ & $0 / 6$ & Usually negative & $0 / 9$ & $1 / 7$ & usually negative & $3 / 28$ & $0 / 2$ & $3 / 30$ \\
\hline Initial CT & ND & ND & $2 / 2$ & $4 / 4$ & $5 / 7$ & ND & $11 / 13$ & $1 / 2$ & $12 / 15$ \\
\hline Initial Bone scan & $4 / 5$ & $4 / 5$ & $4 / 6$ & $9 / 9$ & $5 / 7$ & $2 / 3$ & $28 / 35$ & ND & $28 / 35$ \\
\hline MRI & ND & ND & ND & ND & ND & $5 / 5$ & $5 / 5$ & $2 / 2$ & $7 / 7$ \\
\hline Abscess & $0 / 6$ & $1 / 6$ & NR & $0 / 9$ & $2 / 7$ & NR & $3 / 28$ & $0 / 2$ & $3 / 30$ \\
\hline Antibiotic & NR & $\begin{array}{l}\text { Parenteral } \\
\text { Flucloxacillin } \\
\text { and Fucidin } \\
\text { for } 6 \text { weeks }\end{array}$ & $\begin{array}{l}\text { Most with } \\
\text { extended- } \\
\text { spectrum } \\
\text { penicillin or } \\
\text { Cephalosporin, } \\
\text { 1.5-4 wks IV, } \\
\text { PO 1-24 wks }\end{array}$ & NR & $\begin{array}{c}\text { Oxacillin or } \\
\text { Nafcillin IV } \\
\times 3 \text { weeks, then } \\
\text { P0 antibiotics } \\
\text { ×3 weeks }\end{array}$ & $\begin{array}{c}\text { IV Abx } \\
\text { (not specified) } \\
\text { for 19-50d } \\
\text { (average 29d), } \\
\text { then PO } \\
\text { antibiotics for } \\
\text { 2-3 wks }\end{array}$ & & $\begin{array}{l}\text { IV cephalo- } \\
\text { sporin, then } \\
\text { PO antibiotics } \\
\text { for } 3-6 \text { months }\end{array}$ & \\
\hline Outcome & Cured & Cured & $\begin{array}{l}\text { Cured, } \\
\text { except } 2 \text { w/ } \\
\text { early relapse, } \\
\text { retreated with } \\
\text { full recovery }\end{array}$ & $\begin{array}{l}\text { Cured; one had } \\
\text { contralateral } \\
\text { PS } 2 \text { weeks } \\
\text { after initial, } \\
\text { responded to } \\
\text { antibiotics }\end{array}$ & Cured & Cured & & Cured & \\
\hline $\begin{array}{l}\text { Residual X-ray } \\
\text { changes }\end{array}$ & $6 / 6$ & NR & NR & $2 / 9$ & $4 / 7$ & NR & $12 / 22$ & $0 / 2$ & $12 / 24$ \\
\hline
\end{tabular}

ND, not done; NR, not reported. 
or infection (9 of 28) was previously reported in about one-third of the children previously reported. Neither of our patients had a preceding infection or traumatic injury. Patients presented both acutely or after a subacute course. As with our patients, signs and symptoms were relatively nonspecific, and patients were often admitted with alternative diagnoses. The physical exam was often nonspecific, with difficulty in localizing pain to the SI joint. Aprin and Turen ${ }^{11}$ noted that 7 of 7 patients were positive in the FABERE test. This involves hip flexion, abduction, external rotation, and extension, placing the lateral malleolus on the contralateral knee. Pressing down gently on the ipsilateral knee in this position, stresses an inflamed SI joint and causes pain. Similarly, Ncube ${ }^{8}$ noted that five of six patients had a positive sacroiliac stress test.

Laboratory examinations are non-diagnostic in pyogenic sacroiliitis tending to be variable. White blood cell count and ESR were sometimes elevated but not consistently. Blood cultures were positive in 16 of 32 (50\%; including our 2), while SI joint aspirate cultures were positive in 12 of 15 patients, (67\%; including our 2). In the six case series, as well as with our two patients, Staphylococcus species was the most frequently isolated organism. Coagulase negative Staphylococcus is far less pathogenic than $S$. aureus and may be a contaminant; however it is frequently isolated from patients with chronic osteomyelitis ${ }^{12}$ and may explain the slow progression of symptoms in case \#2. Escherichia coli were identified in two cases and Streptococcus pneumonia in one case.

Roentograms of the hips are generally nondiagnostic in pyogenic sacroiliitis (3 of 30 including current cases). CT scans were positive in 12 of 15 (including current cases) and bone scans in 28 of 35 cases. The study by Doita et $a l .{ }^{13}$ is the only series to include MRI findings which were positive in 5 of 5 cases (7 of 7 including current cases). The authors noted that both MRI and bone scan were sensitive for PS; however, bone scans may be negative if done too early after onset of symptoms. Indeed, Moyer et al. ${ }^{9}$ noted one case where an equivocal bone scan became positive when repeated 30 days later and another where a negative bone scan became positive four days later. In addition, bone scan cannot differentiate PS from psoas or gluteal abscesses or identify infection of adjacent tissue; therefore, MRI may provide more diagnostic accuracy, achieving high sensitivity and specificity. ${ }^{13}$

Traditionally extended-spectrum penicillins or first generation cephalosporins have been the antibiotic of choice. However, methicillinresistant Staphylococcus aureus will require Clindamycin, Linazolid, or TrimethoprimSulfamethoxazole. Most patients had excellent outcomes, although, residual asymptomatic roentogram changes were noted in 12 of 24 (including current cases).

Abscesses were reported in 3 of 30 (including current cases) patients. Though there is little pediatric data with respect to surgical drainage, Hodgson ${ }^{14}$ reported a series of 12 adult patients, of whom 11 had surgical drainage. All had a good outcome, though several had mild residual symptoms and one developed a draining sinus, in contrast to a 30 $40 \%$ mortality rate prior to the antibiotic era. ${ }^{2}$

\section{Conclusions}

Pyogenic sacroiliitis is a relatively uncommon diagnosis in pediatrics. Signs and symptoms can be nonspecific, and physical examination is often unhelpful. The FABERE test is thought to be useful in evaluating the sacroiliac joint. When inflammatory parameters are elevated they are consistent with the diagnosis, but their absence is not reassuring. Blood cultures and aspiration of the SI joint are useful in identifying the infecting agent. While imaging may include roentogram, bone scan, CT, and MRI with varying degrees of sensitivities, the MRI may be the most sensitive in securing the correct diagnosis. Antibiotic therapy initially should be started empirically towards Staphylococcus aureus and then continued for at least three weeks. The optimum duration of therapy is not known, though in most cases antibiotics were continued for six to nine weeks.

In the first case presented, noncompliance with Trimethoprim-Sulfamethoxazole became an issue resulting in a prolonged clinical course requiring a longer total duration of antibiotic therapy. The second case presented subacutely, taking two months to establish a diagnosis. It is unclear whether the patient initially had sacroiliitis that progressed into bony involvement of the sacrum or whether the sacrum was involved first and that pro- gressed to involve the sacroiliac joint. Because of the chronic osteomyelitis, antibiotic treatment was extended in this patient. Consistent with patients previously described in other reports both patients ultimately responded to therapy with good final outcomes.

\section{References}

1. Tse SM, Laxer RM. Approach to acute limb pain in childhood. Pediatr Rev 2006;27: 170-9.

2. Attarian DE. Septic sacroitiitis: the overlooked diagnosis. J South Orthop Assoc 2001;10:57-60.

3. Ford LS, Ellis AM, Allen HW, Campbell DE. Osteomyelitis and pyogenic sacroiliitis: A difficult diagnosis. J Paediatr Child Health 2004;40:317-9.

4. Schaad UB, McCracken GH, Jr., Nelson JD. Pyogenic arthritis of the sacroiliac joint in pediatric patients. Pediatr 1980;66:375-9.

5. Feldman LS. Salmonella septic sacroiliitis: case report and review. Pediatr Infect Dis J 2006;25:187-9.

6. Ariza J, Pujol M, Valverde J, et al. Brucellar sacroiliitis: findings in 63 episodes and current relevance. Clin Infect Dis 1993;16: 761-5.

7. Pourbagher A, Pourbagher MA, Savas L, et al. Epidemiologic, clinical, and imaging findings in brucellosis patients with osteoarticular involvement. Am J Roentgenol 2006; 187:873-80.

8. Ncube BA. Pyogenic sacroiliitis in children. Br J Clin Pract 1988;42:154-7.

9. Moyer RA, Bross JE, Harrington TM. Pyogenic sacroiliitis in a rural population. J Rheumatol 1990;17:1364-8.

10. Abbott GT, Carty H. Pyogenic sacroiliitis, the missed diagnosis? Br J Radiol 1993;66: 120-2.

11. Aprin H, Turen C. Pyogenic sacroiliitis in children. Clinl Orthop Relat Res 1993:98106.

12. Ramos OM. Chronic osteomyelitis in children. Pediatr Infect Dis J 2002;21:431-2.

13. Doita M, Yoshiya S, Nabeshima Y, et al. Acute pyogenic sacroiliitis without predisposing conditions. Spine 2003;28:E384-9.

14. Hodgson BF. Pyogenic sacroiliac joint infection. Clin Orthop Relat Res 1989:1469. 